\title{
NOTHING COMPARES TO YOU: STUDYING THE DIFFICULTIES OF THE STUDENTS IN PROBABILITIES
}

\author{
S. Raposo ${ }^{1}$, Maria M. Nascimento ${ }^{2}$, C. Costa ${ }^{2}$ \\ ${ }^{1}$ Agrupamento de Escolas Morgado de Mateus (PORTUGAL) \\ ${ }^{2}$ Universidade de Trás-os-Montes e Alto Douro (PORTUGAL)
}

\begin{abstract}
The usefulness of probability for daily life, the way in which probability reasoning support decision making and the instrumental role of probability in various curricular areas and professional work has been stated by several authors. In this work we present the semiotic conflicts of an exploratory study with 120 Portuguese secondary school students (ages from 15 to 17) in the northern Portugal, in the academic year $2013 / 2014$, in solving two problems that involve the use of conditional probability, events independence, total probability and Bayes theorems. The Onto-Semiotic Approach was adopted in order to identify and describe the semiotic conflicts that arose in the answers of the students in a survey. The survey was presented in a 50-minute class and had 11 multiple choice questions and students were asked to write the reasons of their choice. In this paper we analyse the answers to questions 4 (based on absolute frequencies) and 9 (based on relative frequencies), and both of them were designed to detect the semiotic conflicts of the students' answers that are mentioned in the literature. As a result, the semiotic conflicts described in the literature were identified and analysed in order to support a plan proposal for classroom approach and its further research.
\end{abstract}

Keywords: Probability, probability reasoning, students, semiotic conflicts.

\section{INTRODUCTION}

The Program of Mathematics Applied to Social Sciences (abbreviated as MASS, [1]) is structured over two years of secondary education in four major themes: graph models; population models; probability models and introduction to statistical inference. In this work, we only focus the probability models. The theoretical framework adopted - in the line with the Spanish and Portuguese researches in teaching and learning of statistics - is the Onto-Semiotic Approach (OSA). In this work we highlight the notion of semiotic conflict defined as "any disparity or difference of interpretation between the meanings attributed to an expression by two subjects (people or institutions)" [2]. This work is part of a broader research and has a qualitative nature and its paradigm is the interpretative one [3]. Its main objective is to promote students' learning in probability models and, in the first stage of the research, the aim was to identify and understand their difficulties in the topics of conditional probabilities, joint probabilities, total probability theorem and Bayes theorem. In this study we focus on MASS probability content a survey was built to detect the semiotic conflicts of the theme. In this way, this paper contributes to answer the question "what are the semiotic conflicts of students in the topic of probabilities in MASS?"

The concepts of conditioned probability, joint probability, total probability and Bayes' theorem in Portugal are taught only in the secondary education. However, several studies (e.g. [4, 5]) state that it would be more appropriate to start teaching them earlier. Also in Portugal, the results reported by Correia et al. [6] and Correia and Fernandes [7] about the concepts of conditioned probabilities that students of the 9th grade (age 15), are encouraging and those researches envisage the possibility to introduce these concepts in the Portuguese 9th grade. In addition, for several authors, including Batanero et al. [8], it is important to understand and to apply the concept of conditional probability in daily life as well as in the professional one. This concept is of important, as it is the basis for other contents, such as joint probability and independence [9]. Fernandes [10] detected that students had been taught the probabilities contents were not distinguished from those who were not in what respects to the errors presented in counterintuitive probabilistic situations. Nonetheless, already in 1984, Fischbein and Gazit [11] showed that for the students is more difficult to compute the conditional probability in experiments without replacement than in experiments with replacement. In what joint probability is concerned, one of the most common errors is the error of the conjunction fallacy [12] in which the students consider the joint probability, $P(A \cap B)$, to be bigger to each of its elements constituents, i.e., $P(A \cap B)>P(A)$ or $P(A \cap B)>P(B)$. 
In other works, the concepts of conditional probability and joint probability are among those who lead students to misconceptions [e.g. 4, 5]. The students do not clearly distinguish the meanings of conditioned probabilities, $\mathrm{P}(\mathrm{A} \mid \mathrm{B})$, and joint probability, $\mathrm{P}(\mathrm{A} \cap \mathrm{B})[13]$ and this confusion emerges when it is necessary to interpret statements with these two different probabilities. These difficulties were also observed in other more recent studies [6,15]. Polaki [14] refers that defining the sample space of composite experiences was another difficulty shown by the students. An additional difficulty is to distinguish between a conditional probability, $P(A \mid B)$, and its transpose, $P(B \mid A)[16]$, this error is known as the fallacy of the transposed. These difficulties were also reported in the context of higher education students in Diaz [17, p.354 and p.374] and in secondary school students in Fernandes et al. [18]. Also in the researches of Díaz and Batanero [19] and of Díaz et al. [20], the fallacy of the time axis inversion was also reported, and it involves in the fact that students do not admit the possibility that the conditioning event may occur after the conditioned event. As reported [e.g. 19, 20] that difficulty is due to adherence to a deterministic view that the probability of something that occurs afterwards cannot influence something that occurred before. Fernandes et al. [18] found those errors in Portuguese students of the 12th grade (age 17), as well as those resulting from them in the application of the total probability theorem or using the Bayes' theorem. In higher education students, these difficulties have also been reported by Silva and Nascimento [21]. According to Díaz et al. [20], in 1992 Totohasina concluded that using a double entry table makes it difficult to perceive the sequential nature of some problems, since only the intersection of events is visible, which may lead students to confuse conditional probability with joint probability. Thus, the use of a tree scheme is preferable to solve such problems. Gigerenzer and Hoffrage [22] suggest that calculations in Bayesian problems are easier when the information is given as absolute frequencies rather than as a percentage. In this work the aim was to make an exploratory study about the students' semiotic conflicts in the topic of probabilities in MASS shown in the answers of two questions 4 (based on absolute frequencies) and 9 (based on relative frequencies) of a survey built on this topic.

The theoretical framework was the Onto-Semiotic Approach (OSA) as it allows the knowledge produced systematization and the need to obtain a clear vision of the concepts that may exist in our perceptions [23]. The OSA is a theoretical framework that integrates several approaches and models used in mathematics teaching and learning research, starting from anthropological and semiotic assumptions about this teaching and of didactic principles of the constructivist and interactionist type for the study of teaching and learning processes $[2,24]$. In summary, this work uses the concept of semiotic conflict to categorize students' learning difficulties - semiotic conflicts detected from their previous learning - didactic trajectory - didactic intervention - using applets - mediator object in order to overcome them. In OSA, starting from the problem situation, theoretical concepts of practice, objects and personal and intentional meanings are defined to make visible the facets of mathematics, as well as the personal and institutional genesis of knowledge as well as their interrelationships [2]. A semiotic conflict is defined "[as] any disparity or difference in interpretation between the meanings attributed to an expression by two subjects (people or institutions)" [2] in that way they are interpretations of mathematical expressions by students who are not in agreement with those that the teacher wishes to communicate them. The OSA authors argue that these semiotic conflicts - that are at the origin of the errors of the students - are not due to lack of knowledge, but to an incorrect interpretation of mathematical expressions or of what the teacher intends them to learn. In this work using the theoretical framework of OSA - answering one of the challenges of Batanero [25] - this work aims to identify the semiotic conflicts in students' learning of probabilities in Portuguese secondary education. Thus, OSA is used in the analysis of students' difficulties in probabilities. The types of mathematical objects (problems, language ...), and the cognitive facets (extensive-intensive, ostensive-not ostensive ...) will characterize institutional meanings (responses to problems elaborated from an expert point of view), as well as the personal meanings of the students [e.g. 2, 24].

\section{METHODOLOGY}

This work has a qualitative nature and its paradigm is the interpretative one since we are trying to understand the semiotic conflicts of the students [3]. We identified the difficulties and errors of the students in the subject of probabilities taught in secondary education and MASS: conditional probability, joint probability, total probability, and Bayes theorems, based on the semiotic conflicts shown in the students answers. To do it a survey was built and 120 students tested it at Portuguese Mathematics A of the 12th grade (age 17) and at the Portuguese MASS 11th grade (ages 16 and 17), from three secondary schools in the northern interior of Portugal, after the teaching of the probabilities chapter. The survey was answered in a 50-minute class and had 11 multiple-choice questions, with items. The students had to choose the correct answer from four presented hypotheses, and had to 
write the reasons of their choice - resolution and computations. The contents covered in all the questions of the survey and the context of the questions are summarized in Table 1. In this work, we present the analysis to the answers to questions 4 and 9. Both multiple-choice answers were written taking in consideration the possible semiotic conflicts that might rise (or not). In addition, question 4 was based on the absolute frequencies (counts) and question 9 was based on the relative frequencies (percentages), as reported in literature [22]. The students' answers analysis and the results will be presented in the next paragraph tables. Finally, the percentages differences test was performed ( $p$ value computed) in order to statistically validate the answers percentages in the items of questions 4 and 9 .

Table 1. Content and context of the survey questions.

\begin{tabular}{|c|c|c|c|c|c|c|}
\hline \hline Survey Questions & \multicolumn{5}{|c|}{ Context } \\
\hline Content & $\begin{array}{c}\text { Bag/box } \\
\text { with balls }\end{array}$ & Cards & Coins & Dice & $2 \times 2$ table & $\begin{array}{c}\text { Real world } \\
\text { problem }\end{array}$ \\
\hline $\begin{array}{c}\text { Classical definition of } \\
\text { probability }\end{array}$ & $1 . a)$ & $2 . a)$ & & & $8 . b)$ & \\
\hline Joint probability & $4 . b)$ & & & & & $9 . b)$ \\
\hline Mutually exclusive events & & & & & $8 . a)$ & \\
\hline Conditional prob. & 1.b), 4.a) & $2 . b), 2 . c)$ & & & $8 . c)$ & \\
\hline Events independency & 3. & & 5. & 7. & $8 . d)$ & 6. \\
\hline $\begin{array}{c}\text { Theorem of total } \\
\text { probability }\end{array}$ & $4 . c)$ & & & & & $\begin{array}{c}9 . a), 9 . c), \\
11 . a)\end{array}$ \\
\hline Bayes' theorem & 4.d) & & & & & 9. d), 11.b) \\
\hline \hline
\end{tabular}

\section{ANALYSIS OF RESULTS}

The semiotic conflicts found will be mentioned as: $\mathrm{C} 1$ - conflict not to identify that this is a random experiment without replacement; C2 - conflict when considering joint probabilities as conditional probabilities; C3 - conflict when considering the conditioned probability as being the conditioned probability transposed; C4 - conflict by not identifying that the conditioning event may occur after conditioning.

\subsection{Question 4}

Fig. 1 presents question 4 and Table 2 presents the analysis of question 4 summarizing its contents, aims, and the semiotic conflicts of the items answers options. In order to analyse this question the events were considered: $\mathrm{B}_{1}$ : "The first ball extracted is white"; $\mathrm{B}_{2}$ : "The second extracted ball is white"; $\mathrm{P}_{1}$ : "The first ball drawn is black"; $\mathrm{P}_{2}$ : "The second extracted ball is black".

\section{QUESTION 4}

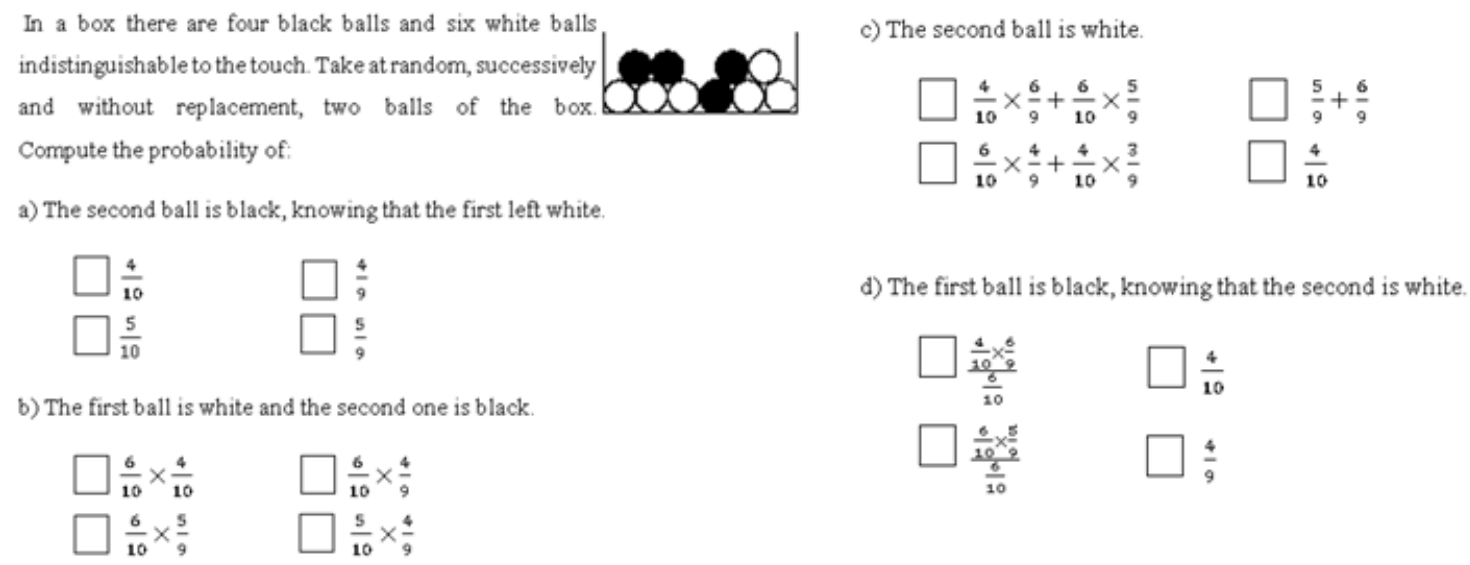

Figure 1. Question 4 
Table 2. Analysis of question 4: contents, aims, and semiotic conflicts of the options

\begin{tabular}{|c|c|c|c|}
\hline $\begin{array}{l}\text { 4.a) } \\
{[17, \text { p. 228] }}\end{array}$ & $\begin{array}{l}\text { Conditional } \\
\text { probability }\end{array}$ & $\begin{array}{l}\text { Change the sample space } \\
\text { of a random experience and } \\
\text { then apply the classical } \\
\text { definition of probability }\end{array}$ & $\begin{array}{l}\text { (A) C1 } \\
\text { (B) C2 } \\
\text { (C) Correct answer } \\
\text { (D) C3 }\end{array}$ \\
\hline $\begin{array}{l}4 . b) \\
{[21]}\end{array}$ & $\begin{array}{l}\text { Joint } \\
\text { probability }\end{array}$ & $\begin{array}{l}\text { Applying the definition of } \\
\text { joint probability for two } \\
\text { events }\end{array}$ & $\begin{array}{l}\text { (A) C1 } \\
\text { (B) Confusion between } P\left(B_{1} \cap B_{2}\right) \text { and } P\left(B_{1} \cap P_{2}\right) \\
\text { (C) Correct answer } \\
\text { (D) C2 }\end{array}$ \\
\hline $\begin{array}{l}4 . c) \\
{[26]}\end{array}$ & $\begin{array}{l}\text { Total } \\
\text { probability } \\
\text { theorem }\end{array}$ & $\begin{array}{l}\text { Using absolute frequencies } \\
\text { applying the theorem }\end{array}$ & $\begin{array}{l}\text { (A) Correct answer } \\
\text { (B) C1 } \\
\text { (C) C2 } \\
\text { (D) C4 }\end{array}$ \\
\hline $\begin{array}{l}\text { 4.d) } \\
{[27, \text { p. 305] }}\end{array}$ & $\begin{array}{l}\text { Bayes } \\
\text { theorem }\end{array}$ & $\begin{array}{l}\text { Using absolute frequencies, } \\
\text { compute probabilities using } \\
\text { the theorem }\end{array}$ & $\begin{array}{l}\text { (A) Correct answer } \\
\text { (B) C2 } \\
\text { (C) C4 } \\
\text { (D) C3 }\end{array}$ \\
\hline
\end{tabular}

Regarding answers to question 4a (Table 3) $75 \%$ of the students answered correctly (Fig. 2, left), and $10 \%$ of the students showed semiotic conflict $\mathrm{C} 1$ since students did not identify the random experiment as a random experiment without replacement. The remaining students $\mathrm{C} 2$ semiotic conflict was also detected since they did not identify the conditional probabilities but they considered them as joint probabilities, as well as $\mathrm{C} 3$ semiotic conflict (Fig. 2, right) since students did not identify the conditioned probability asked, but considered it as being the conditioned probability transposed.

Table 3. Analysis of question $4 a$

\begin{tabular}{|l|c|}
\hline \hline Option & Count (\%) \\
\hline Correct answer & $12(75)$ \\
\hline $\begin{array}{l}\text { Does not identify that is a random experience without } \\
\text { replacement (C1) }\end{array}$ & $8(7)$ \\
\hline $\begin{array}{l}\text { Does not identify that is a conditional probabilities but } \\
\text { considered it as joint probabilities (C2) }\end{array}$ & $10(8)$ \\
\hline $\begin{array}{l}\text { Does not identify the conditioned probability asked, but as } \\
\text { being the conditioned probability transposed (C3) }\end{array}$ & $120(100)$ \\
\hline Total & \\
\hline \hline
\end{tabular}
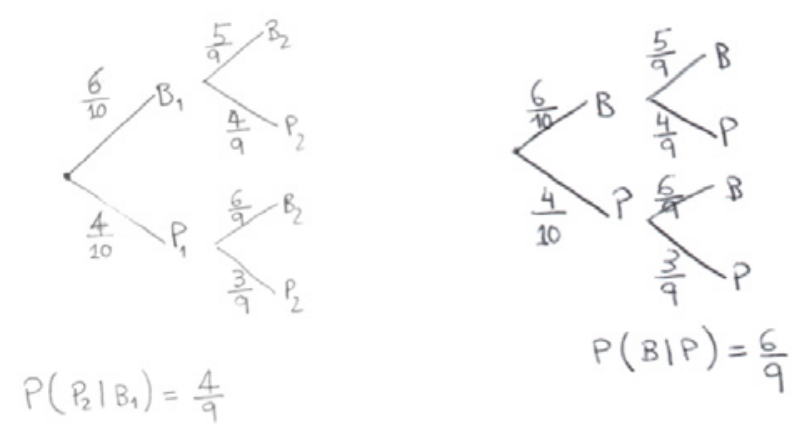

Figure 2. Correct answer (left) and C3 semiotic conflict (right)

In answers to question 4.b (Table 4) $74 \%$ of the students answered correctly and $13 \%$ of the students showed again that the $\mathrm{C} 1$ semiotic conflict since students did not identify the random experiment as a random experiment without replacement (C1). 
Table 4. Analysis of question $4 b$

\begin{tabular}{|l|c|}
\hline \hline Option & Count (\%) \\
\hline Correct answer & $89(74)$ \\
\hline Does not identify that is a random experience without replacement (C1) & $15(13)$ \\
\hline Does not identify the elements needed to calculate the probability & $4(3)$ \\
\hline $\begin{array}{l}\text { Does not identify that is a conditional probabilities but considered it as joint } \\
\text { probabilities (C2) }\end{array}$ & $12(10)$ \\
\hline Total & $120(100)$ \\
\hline
\end{tabular}

Concerning answers to question 4.c (Table 5) only $38 \%$ of the students answered correctly and $18 \%$ of students showed once again the C1. C2 semiotic conflict appeared in $23 \%$ answers since students did not identify the conditional probabilities but they considered them as joint probabilities. Finally, $21 \%$ of the students showed C4 semiotic conflict because those students did not identify that the conditioning event may occur after the conditioned event.

Table 5. Analysis of question $4 c$

\begin{tabular}{|l|c|}
\hline \hline Option & Count (\%) \\
\hline Correct answer & $46(38)$ \\
\hline Does not identify that is a random experience without replacement (C1) & $21(18)$ \\
\hline $\begin{array}{l}\text { Does not identify that is a conditional probabilities but considered it as joint } \\
\text { probabilities (C2) }\end{array}$ & $28(23)$ \\
\hline Does not identify that the conditioning event may occur after conditioning (C4) & $25(21)$ \\
\hline Total & $120(100)$ \\
\hline \hline
\end{tabular}

In the last item answers question $4 . d$ (Table 6 ) only $35 \%$ of the students answered correctly and $19 \%$ of the students presented C1 semiotic conflict; $25 \%$ presented either C2 semiotic conflict, or $21 \%$ C4 semiotic conflict.

Table 6. Analysis of question 4d

\begin{tabular}{|l|c|}
\hline \hline Option & Count (\%) \\
\hline Correct answer & $42(35)$ \\
\hline Does not identify that is a random experience without replacement (C1) & $23(19)$ \\
\hline $\begin{array}{l}\text { Does not identify the conditioned probability asked, but as being the conditioned } \\
\text { probability transposed (C3) }\end{array}$ & $30(25)$ \\
\hline Does not identify that the conditioning event may occur after conditioning (C4) & $25(21)$ \\
\hline Total & $120(100)$ \\
\hline \hline
\end{tabular}

\subsection{Question 9}

Fig. 3 presents question 9 and Table 7 presents the analysis of question 9 summarizing its contents, aims, and the semiotic conflicts of the items answers options. In order to analyse this question the events were considered: A: "Payment is made by credit card"; B: "Payment is made by debit card"; C: "Payment is made in cash"; M: "The payment is more than one hundred euros". 


\section{QUESTION 9}

In the last sales season in a store, $25 \%$ of the purchases were done with credit card, $40 \%$ with debit card and the remaining in cash. It is known that $20 \%$ of the purchases were made with credit card, $10 \%$ of the purchases were made with debit card and $15 \%$ of the purchases made in money were more than 100 euros

Choosing a purchase at random, what is the probability of:

a) The purchase was made in cash?

$\begin{array}{ll}\square^{0,65} & \square{ }^{0,65} \\ \square^{0,40} & \square^{0,35}\end{array}$

b) The purchase was made in cash and more than 100 euros were spent?

$\begin{array}{ll}\square^{0,35} & \square^{\frac{0.15}{0.35}} \\ \square^{0,15} & \square 0,15 \times 0,35\end{array}$

c) In the purchase more than 100 euros were spent?

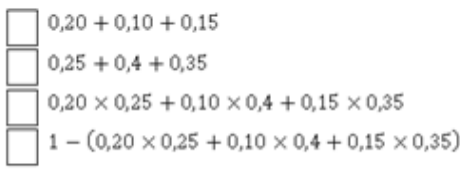

d) The purchase was made in cash, knowing that more than 100 euros were spent?

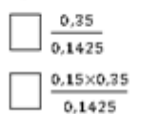

Figure 3. Question 9

Table 7. Analysis of question 9: contents, aims, and semiotic conflicts of the options

\begin{tabular}{|l|l|l|l|}
\hline \hline $\begin{array}{l}\text { 9.b) } \\
{[20]}\end{array}$ & $\begin{array}{l}\text { Joint } \\
\text { probability }\end{array}$ & $\begin{array}{l}\text { Applying the definition } \\
\text { of joint probability for } \\
\text { two events }\end{array}$ & $\begin{array}{l}\text { (A) Confusion between } \mathrm{P}(\mathrm{C}) \text { and } \mathrm{P}(\mathrm{C} \cap \mathrm{M}) \\
\text { (B) C2 }\end{array}$ \\
\hline & $\begin{array}{l}\text { (C) Confusion with } P(C \cap M)=P(C)+P(M) \\
\text { (D) Correct answer }\end{array}$ \\
$9 . \mathrm{C})$ & $\begin{array}{l}\text { Total } \\
\text { Probability } \\
\text { theorem }\end{array}$ & $\begin{array}{l}\text { Using absolute } \\
\text { percentages applying } \\
\text { the theorem }\end{array}$ & $\begin{array}{l}\text { (A) C2 } \\
\text { (B) Confusion between total probability theorem and } \\
\text { partition } \\
\text { (C) Correct answer }\end{array}$ \\
\hline $\begin{array}{l}\text { 9.d) } \\
{[27, p .305]}\end{array}$ & $\begin{array}{l}\text { Bayes } \\
\text { theorem }\end{array}$ & $\begin{array}{l}\text { Using percentages, } \\
\text { compute probabilities } \\
\text { using the Bayes } \\
\text { theorem }\end{array}$ & $\begin{array}{l}\text { (A) C2 } \\
\text { (B) Correct answer }\end{array}$ \\
\hline \hline
\end{tabular}

In what concerns to answers question $9 \mathrm{~b}$ (Table 8 ), only $53 \%$ of the students answered correctly and $29 \%$ did not identify that were a conditional probabilities but considered it as joint probability (C2). The other students did another type of error that was not referred to in the literature (Fig. 4, Ca1 on the left and $\mathrm{Ca} 2$ on the right).

Table 8. Analysis of question $9 b$

\begin{tabular}{|l|c|}
\hline \hline Option & Count (\%) \\
\hline Correct answer & $63(53)$ \\
\hline $\begin{array}{l}\text { Does not identify that is a conditional probabilities but } \\
\text { considered it as simple probability (Ca1) }\end{array}$ & $12(10)$ \\
\hline $\begin{array}{l}\text { Does not identify that is a conditional probabilities but } \\
\text { considered it as joint probabilities (C2) }\end{array}$ & $28(23)$ \\
\hline $\begin{array}{l}\text { Does not identify that is a conditional probabilities but } \\
\text { considered it as a sum of two simple probabilities (Ca2) }\end{array}$ & $17(14)$ \\
\hline Total & $120(100)$ \\
\hline \hline
\end{tabular}




$$
\begin{aligned}
P(\pi \cap c) & =P(\pi)+P(c) \\
& =0,15+0,35 \\
& =0,50
\end{aligned}
$$

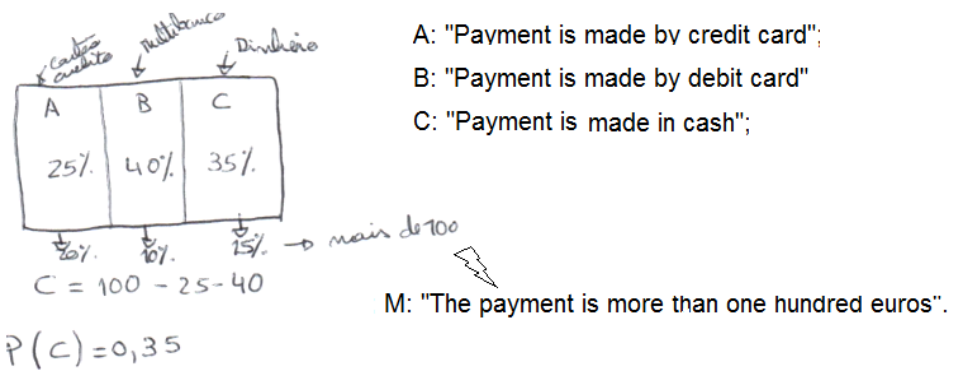

Figure 4. Wrong answers (Ca1 on the left and Ca2 on the right)

In question 9 item c (Table 9), 31\% of the students answered correctly and $29 \%$ did not identify that were a conditional probabilities but considered it as joint probability (C2). As in answers to questions $9 \mathrm{~b}$, the remaining students did another type of error that was not referred to in the literature.

Table 9. Analysis of question 9c

\begin{tabular}{|l|c|}
\hline \hline \multicolumn{1}{|c|}{ Option } & Count (\%) \\
\hline Correct answer & $37(31)$ \\
\hline Does not identify that is a conditional probabilities but considered it as joint probabilities (C2) & $35(29)$ \\
\hline $\begin{array}{l}\text { Does not identify that is a conditional probabilities but considered it as a sum of three simple } \\
\text { probabilities }\end{array}$ & $27(23)$ \\
\hline Does not identify that is a conditional probabilities but considered the opposite event & $21(17)$ \\
\hline Total & $120(100)$ \\
\hline \hline
\end{tabular}

In question 9 item d (Table 10), 30\% of the students answered correctly and $27 \%$ of the students did not correctly identify the conditional probability requested, but rather its transpose (C3); $22 \%$ did not identify that the conditioning event could occur after conditioning (C4), and $21 \%$ did not identify that is a conditional probabilities but considered it as joint probabilities (C2).

Table 10. Analysis of question $9 d$

\begin{tabular}{|l|c|}
\hline \hline \multicolumn{1}{|c|}{ Option } & Count (\%) \\
\hline Option & Count (\%) \\
\hline Correct answer & $36(30)$ \\
\hline Does not identify that is a conditional probabilities but considered it as joint probabilities (C2) & $25(21)$ \\
\hline $\begin{array}{l}\text { Does not identify the conditioned probability asked, but as being the conditioned probability } \\
\text { transposed (C3) }\end{array}$ & $33(27)$ \\
\hline Does not identify that the conditioning event may occur after conditioning (C4) & $26(22)$ \\
\hline \hline
\end{tabular}

Comparing the results in both questions (Table 11), the percentage of correct answers decreased. Concerning the pair of questions $4 \mathrm{~b}-9 \mathrm{~b}$ the performance of the students was bigger than $50 \%$ and the proportions difference test considers them different, since it is has statically significant difference ( $p$ value $<0.05$ ). Regarding the two pairs of questions $4 c-9 c$ and $4 d-9 d$, the performance of the students was less than $50 \%$ and the proportions difference test considers them equal, i.e., their difference is not statically significant $(p-v a l u e ~>0.05)$.

Table 11. Comparing the results in the two questions

\begin{tabular}{|l|c|c|c|c|c|c|}
\hline \hline \multicolumn{1}{|c|}{ Comparing the results in the two questions } & \multicolumn{2}{|c|}{ Joint probability } & \multicolumn{2}{c|}{$\begin{array}{c}\text { Total probability } \\
\text { theorem }\end{array}$} & \multicolumn{3}{|c|}{$\begin{array}{c}\text { Bayes } \\
\text { theorem }\end{array}$} \\
\hline Question & $4 \mathrm{~b}$ & $9 \mathrm{~b}$ & $4 \mathrm{c}$ & $9 \mathrm{c}$ & $4 \mathrm{~d}$ & $9 \mathrm{~d}$ \\
\hline Correct answers (\%) & 74 & 53 & 38 & 31 & 35 & 30 \\
\hline p-value for the percentages differences test & \multicolumn{2}{|c|}{0,0003} & \multicolumn{2}{|c|}{0,2056} & \multicolumn{2}{|c|}{0,2038} \\
\hline \hline
\end{tabular}




\section{CONCLUSIONS}

From the analysis of the results, some of the difficulties found were effectively those described in the literature review. Namely, difficulty in not identifying that it is a random experiment without replacement (e.g. [6]); difficulty in considering joint probabilities as being conditional probabilities (e.g. [6]); difficulty in considering the conditioned probability as being the conditional probability transposed and difficulty in not identifying that the conditioning event may occur after conditioning (e.g. [18]). The only statistically significant the percentage difference was for the joint probability (Table 11) where more students correctly answered with data expressed in absolute frequency (counts, question 4d) than with data expressed in relative frequency (percentages, question 9) [22].

Based on the results, we were able to list the semiotic conflicts in the students' answers in the topic of probabilities taught in secondary education: conditional probability, joint probability, total probability, and Bayes theorems. These conflicts were more or less the same found in the literature [e.g. 5, 11, $12,13,14]$, but in questions $9 \mathrm{~b}$ and $9 \mathrm{c}$ other types of conflict were listed, mainly misinterpretation of the problem text and of the needed computations. In order to avoid those conflicts would be more appropriate to start teaching probability concepts in earlier ages $[4,5]$.

To reinforce this work, we are aware that a bigger number of have to be collected in order to obtain a more representative sample of the secondary (including MASS) of Portuguese students. This work was important because it made possible to confirm other researches results and thus supporting a different design to approach learning to the probability contents using technology.

\section{ACKNOWLEDGEMENTS}

This work is financially supported by National Funds through FCT - Fundação para a Ciência e a Tecnologia, I.P., under the project UID/CED/00194/2013.

\section{REFERENCES}

[1] ME, Ministério da Educação, "Programa de Matemática Aplicada às Ciências Sociais," Lisboa, Portugal: Ministério da Educação, Departamento da Educação Básica, 2001.

[2] J. D. Godino, C. Batanero, V. Font, "The Onto-semiotic approach to research in mathematics education," ZDM-The International Journal on Mathematics Education, 39, vols.1-2, pp. 127135, 2007. Retrieved on 30.06.2013: http://www.ugr.es/local/jgodino/

[3] L. Cohen, L. Mannion, K. Morrison, Research Methods in Education (7th Ed.). London \& New York: Routledge, 2011.

[4] J. E. Tarr, G. A. Jones, "A framework for assessing middle school students' thinking in conditional probability and independence". Mathematics Education Research Journal, 9, vol. 1, pp. 39-59, 1997.

[5] J. E. Tarr, J. K. Lannin, "How can teachers build notions of conditional probability and independence?," Exploring probability in school: challenges for teaching and learning (G. A. Jones Ed.), pp. 215-238. New York, NY: Springer, 2005.

[6] P. F. Correia, J. A. Fernandes, J. M. Contreras, "Intuições de alunos do $9^{\circ}$ ano de escolaridade sobre probabilidade condicionada," (C. Nunes, A. Henriques, A. Caseiro, A. Silvestre, H. Pinto, H. Jacinto, J. Ponte, Orgs.), Actas do XXII Seminário de Investigação em Educação Matemática. Lisboa, Portugal: Associação de Professores de Matemática, 2011.

[7] P. F. Correia, J. A. Fernandes, "Caracterização das intuições de alunos do $9^{\circ}$ ano em independência e probabilidade condicionada," (J. A. Fernandes, F. Viseu, M. H. Martinho, P. F. Correia, Orgs.), Atas do III Encontro de Probabilidades e Estatística na Escola, 2013.

[8] C. Batanero, J. A. Fernandes, J. M. Contreras, "Un análisis semiótico del problema de Monty Hall e implicaciones didácticas," Suma, 62, pp. 11-18. 2009.

[9] M. Borovcnik, "Multiple perspectives on the concept of conditional probability," Avances de Investigación en Educación Matemática, 2, pp. 5-27, 2012. 
[10] J. A. Fernandes, "Intuições e aprendizagem de probabilidades: uma proposta de ensino de probabilidades no $9^{\circ}$ ano de escolaridade," Not published P.h.D. Thesis, Braga, Portugal: Universidade do Minho,1999.

[11] E. Fischbein, A. Gazit, "Does the teaching of probability improve probabilistic intuitions?" Educational Studies in Mathematics, 15, pp.1-24. 1984.

[12] A. Tversky, D. Kahneman, "Extensional versus intuitive reasoning: The conjunction fallacy in probability judgment," Psychological Review, 90, vol. 4, pp. 293-315, 1983.

[13] A. Pollatsek, A. D. Well, C. Konold, P. Hardiman, "Understanding conditional probabilities," Organitation, Behavior and Human Decision Processes, 40, pp. 255-269, 1987.

[14] M. V. Polaki, "Dealing with compound events," Exploring probability in school: challenges for teaching and learning (G. A. Jones Ed.), pp. 191-214). New York: Springer, 2005.

[15] A. Estrada, C. Díaz, "Computing probabilities from two way tables: an exploratory study with future teachers," (A. Rossman, B. Chance, Eds.), Proceedings of Seventh International Conference on Teaching of Statistics. Salvador (Bahia): International Association for Statistical Education, 2006.

[16] R. Falk, "Conditional probabilities: Insights and difficulties," (R. Davidson, J. Swift Eds.), Proceedings of Second International Conference on Teaching Statistics, pp. 292-297. Victoria, BC: University of Victoria, 1986.

[17] Díaz, C. "Viabilidad de la enseñanza de la inferencia bayesiana en el análisis de datos en psicología," P.h.D. Thesis, Granada, Spain: Universidad de Granada, 2007.

[18] J. A. Fernandes, M. M. Nascimento, M. C. Cunha, J. M. Contreras, "Desenvolvimento do conceito de probabilidade condicionada em alunos do $12 .^{\circ}$ ano através do ensino," Actas da XIII Conferência Interamericana de Educação Matemática, Recife, Brasil, 2011.

[19] C. Díaz, C. Batanero, "University students' knowledge and biases in conditional probability reasoning," International Electronic Journal of Mathematics Education 4, vol. 3, pp. 131-162, 2009.

[20] C. Díaz, J. M. Contreras, C. Batanero, R. Roa, "Evaluación de sesgos en el razonamiento sobre probabilidad condicional en futuros profesores de educación secundaria," Bolema, 26, vol. 22, pp.1207-1226, 2012.

[21] H. Silva, M. M. Nascimento. Estudo sobre a resolução de problemas que envolvem o teorema de Bayes. Actas do XXI Seminário de Investigação em Educação Matemática (H. Gomes, L. Menezes, \& I. Cabrita Orgs.), pp. 341-356. Lisboa, portugal: Associação de Professores de Matemática, 2010.

[22] G. Gigerenzer, U. Hoffrage, "How to improve Bayesian reasoning without instruction: Frequency formats," Chicago: University of Chicago, 1995.

[23] J. D. Godino, "Hacia una teoría de la Didáctica de la Matemática," Área de conocimiento: Didáctica de la Matemática (A. Gutiérrez Ed.), pp.105-148. Madrid: Síntesis, 1991.

[24] J. D. Godino, C. Batanero, V. Font, "Um enfoque onto-semiótico do conhecimento e a instrução matemática," Revista de Ensino de Ciências e Matemática, 10, vol. 2, pp. 1-32, 2008. Retrieved on 30.06.2013: http://www.ugr.es/local/jgodino/

[25] C. Batanero, "Los retos de la cultura estadística," Jornadas Interamericanas de Enseñanza de la Estadística, Buenos Aires. Opening Conference, 2002. Retrieved on 30.06.2013: http://www.ugr.es/ batanero

[26] C. Díaz, I. de la Fuente, "Dificultades en la resolución de problemas que involucran el Teorema de Bayes. Un estudio exploratorio en estudiantes de psicología," Educación Matemática, 18, vol. 2, pp.75-94, 2007.

[27] M. Aliaga, B. Gunderson, Interactive Statistics (3rd Ed). New Jersey: Prentice Hall, 2006. 